\title{
A Fresh Perspective on Historical Sexual Abuse: The Case of Hewitt v S 20171 SACR 309 (SCA)
}

\author{
W Nortje ${ }^{\star}$ and P du Toit ${ }^{\star \star}$
}

\section{P.E.R}

Pioneer in peer-reviewed, open access online law publications

Authors

Windell Nortje

Pieter du Toit

Affiliations

University of the Western Cape South Africa

North-West University, South Africa

Email

wnortje@uwc.ac.za

pieter.dutoit@nwu.ac.za

Date published

18 December 2017

Editor Prof O Fuo

How to cite this article

Nortje W and Du Toit P "A Fresh Perspective on Historical Sexual Abuse: The Case of Hewitt $v S$ 20171 SACR 309 (SCA)" PER / PELJ 2017(20) - DOI

http://dx.doi.org/10.17159/17273781/2017/v20i0a2229

\section{Copyright}

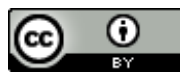

DOI

http://dx.doi.org/10.17159/17273781/2017/v20i0a2229

\begin{abstract}
Sexual crimes continues to be a scourge in our society. It is therefore not surprising that the prevention and criminalisation of sexual crimes in South Africa has received a large amount of attention over the last few years. Contrarily, the matter of historical sexual abuse has received only occasional consideration. Cases of historical sexual abuse present numerous challenges to all parties involved. The victims of historical sexual abuse, often children at the time, are now adults. Some of these victims might not want to relive the experience or confront the offender. On the other hand, the offender might have been rehabilitated and become a respected citizen. In Hewitt v S 20171 SACR 309 (SCA) the Supreme Court of Appeal heard the appeal against the sentence of Bob Hewitt, a retired tennis champion. He was convicted of committing numerous sexual offences against young girls. The first of these crimes was committed more than three decades ago. This case note analyses the decision by the SCA while it also examines historical sexual abuse more generally in South Africa as well as in England and Wales, in order to establish whether any lessons can be learned from previous cases and laws as implemented in these countries.
\end{abstract}

\section{Keywords}

Sexual crimes; historical sexual abuse; rape; children; sports icon; Bob Hewitt; mitigating factors; aggravating factors; remorse; sentencing. 


\section{Introduction}

Rape and sexual abuse, amongst other violent sexual crimes, continues to be a scourge in our society. It is therefore not surprising that the prevention and criminalisation of sexual crimes in South Africa has received a large amount of attention over the last few years. Contrarily, the matter of historical sexual abuse has received only occasional consideration. ${ }^{1}$ Cases of historical sexual abuse present numerous challenges to all parties involved. The victims of historical sexual abuse, often children at the time, are now adults. Some of these victims might not want to relive the experience or confront the offender. On the other hand, the offender might have been rehabilitated and become a respected citizen. In some cases, the offender is a citizen who is highly regarded by the community and might even be protected by an organisation. For instance, catholic priests who were accused of sexually abusing children were protected by the Catholic Church in the late 1990s. This and other implications pose major obstacles for the victims of such crimes. These are only some of the challenges facing the court upon the conviction and sentencing of an offender who has been accused of committing historical sexual abuse.

In Hewitt $v S^{2}$ the Supreme Court of Appeal (SCA) heard the appeal against the sentence of Bob Hewitt, a retired tennis champion (the appellant) with the leave of the Gauteng Division of the High Court, Pretoria. The court a quo had sentenced the appellant to an effective six years' imprisonment. ${ }^{3}$ He had been convicted of committing numerous sexual offences against young girls, the first of these crimes having been committed more than three decades previously. The appellant, a retired tennis champion and instructor, was 75 years old at the time of the imposition of the sentence. ${ }^{4}$

This case note will focus partly on the sentencing of the appellant and the decision by the SCA to dismiss the appellant's appeal with special reference to the mitigating and aggravating circumstances. Moreover, this contribution will briefly examine historical sexual abuse in South Africa as well as in

Windell Nortje. LLB (NWU); LLM (UWC); LLD (UWC). Associate Lecturer, Faculty of Law, University of the Western Cape, South Africa. Email: wnortje@uwc.ac.za.

** $\quad$ Pieter du Toit. B luris, LLB (UOFS); LLM (UJ); LLD (NWU). Professor, Faculty of Law, North-West University (Potchefstroom), South Africa. Email: pieter.dutoit@nwu.ac.za.

1 However, the quantum of research pertaining to the sexual abuse of children by Catholic priests has increased since the late twentieth century. See Guerzoni and Graham 2015 IJCJ\&SD 59.

Hewitt v S 20171 SACR 309 (SCA) (hereafter Hewitt v S).

Hewitt $v S$ para 1.

Hewitt $v S$ para 1. 
England and Wales, in order to establish whether any lessons can be learned from previous cases and laws as implemented in these countries. ${ }^{5}$

\section{The facts}

The facts giving rise to this case are spread over a few decades. Bob Hewitt was convicted by the court a quo of two counts of rape of two girls (the first and second complainant) as well as the indecent assault of another young girl (the third complainant). ${ }^{6} \mathrm{He}$ was convicted in March 2015 at the age of 75 years. ${ }^{7}$ The first and second complainants were raped in the early 1980 s, while the third complainant's ordeal happened in $1994 .{ }^{8}$ The appellant was a well-respected sports icon who coached up-and-coming young tennis stars soon after his retirement from the game as a professional.

He raped the first complainant, a 12-year-old girl, at a Boksburg tennis club during a scheduled tennis lesson one afternoon. ${ }^{9}$ The complainant reported the incident to her mother. However, she did not have a good relationship with her mother, who dismissed the matter. ${ }^{10}$

The second complainant had been thirteen years old. The appellant wrote her love letters, forced her to perform oral sex on him and raped her on a single occasion at a tennis tournament at Sun City near Rustenburg. ${ }^{11}$ The complainant revealed the ordeal to her sister shortly after the incident. ${ }^{12}$ The complainant and the sister then told their parents what had occurred. ${ }^{13} \mathrm{~A}$ charge was laid at the Johannesburg Police Station, but the matter was aborted since the Attorney General determined that the matter had taken place in what was then the Republic of Bophuthatswana, which fell outside his jurisdiction. ${ }^{14}$ Moreover, the complainant's lawyers were also of opinion that the complainant would not withstand cross-examination by the appellant's lawyers in case of a trial. ${ }^{15}$

The third complainant's ordeal took place over a number of years during the 1990s. ${ }^{16}$ The appellant molested the 17 -year-old teenager on numerous

5 It is important to consider foreign law, such as the applicable laws in England and Wales, since s 39(1)(c) of the Constitution of the Republic of South Africa, 1996, emphasises that foreign law may be considered by any court, forum or tribunal.

Hewitt $v$ S para 1.

Hewitt $v S$ para 1.

Hewitt $v$ S para 2.

Hewitt $v S$ para 2.

Hewitt $v S$ para 2.

Hewitt $v S$ para 2.

Hewitt $v S$ para 3.

Hewitt $v S$ para 3.

Hewitt $v S$ para 3.

Hewitt $v S$ para 3.

Hewitt $v S$ para 4. 
occasions. The court also accepted the evidence of the complainant when she testified that on one occasion the appellant told her that "rape is enjoyable in all cases" and that she should "just lie down and enjoy it". ${ }^{17}$ The appellant never raped the complainant, but it was after this remark by the appellant that the complainant decided to tell her mother and her father about the molestation, who reported the appellant to the South African Tennis Association. ${ }^{18}$ The appellant was subsequently forced to resign from the Eastern Transvaal Tennis Association. ${ }^{19}$ Yet again, no charge was laid since the lawyers of the complainant believed that it would have been difficult to prove the charge of indecent assault as there had been no witnesses to the event and the case would rest solely on the complainant's word against the appellant's. ${ }^{20}$

Hence the appellant evaded justice until 2015, when he was finally charged, convicted and sentenced for the crimes he had committed. The appellant was sentenced by the court of first instance to undergo eight years' imprisonment each for the two rape charges, and two years' imprisonment for the charge of indecent assault.. ${ }^{21}$ The sentences were ordered to run concurrently. Two years of each of the rape sentences were suspended for a period of two years on condition that the appellant pay R100 000 to the Department of Justice and Constitutional Development for their campaign against the abuse of women and children..$^{22}$ In effect, he was sentenced to six years imprisonment - the sentence that was on appeal at the SCA.

\section{Appeal to the SCA}

\subsection{Findings of the court}

The grounds of the appellant's appeal were that the sentences imposed by the court a quo were inappropriate as it was contended by the defence that the High Court overemphasised the seriousness of the crimes at the expense of the appellant's personal circumstances, such as his failing health. ${ }^{23}$

The SCA balanced the mitigating and aggravating circumstances against one another to determine whether the High Court's sentence was fair. This consideration was diligently illustrated by the Court:

Hewitt $v S$ para 4.

Hewitt $v S$ para 4.

Hewitt $v S$ para 4.

Hewitt $v S$ para 4.

Hewitt $v S$ para 1.

Hewitt $v S$ para 1.

Hewitt $v S$ para 7. 
Scrupulous care must be taken not to over-emphasise the appellant's personal circumstances without balancing those considerations properly against the very serious nature of the crimes committed; the aggravating circumstances and the consequences for the victims and the interests of society. ${ }^{24}$

\subsubsection{Mitigating factors}

The SCA first considered the appellant's personal circumstances, which were presented in detail to the court a quo during argument for the mitigation of sentence. His deteriorating health and the effect of the trial on his personal life were two of the main mitigating factors. ${ }^{25}$ Moreover, the High Court's judgment included the fact that the appellant was a first offender, had been married for over 50 years and had two children and seven grandchildren. ${ }^{26}$ The High Court also accepted the evidence that the appellant had received a quantity of hate mail and had had to endure hostility from the public and the media. ${ }^{27}$

The Court discussed his failing health in great detail. The court accepted the evidence that the appellant suffered from various conditions impeding his health, including osteoarthritis, progressive coronary artery disease, peptic ulcer disease and a dysfunctional colon, for all of which he was receiving medical treatment. ${ }^{28}$ The SCA referred to the observation of the court a quo that the appellant's conditions were under control and that he was not suffering from a terminal or incapacitating illness. ${ }^{29}$ Coupled with the fact that he was leading an active life, was running a commercial citrus farm, and was able to drive to work and back home on a daily basis, this served only as confirmation to the Court that the appellant's health was in a fairly good state, and could not be regarded as a bar to sentencing. ${ }^{30}$ In addition, the court held that it had been rightly argued by the State that he would be able to receive the necessary medical care in prison. ${ }^{31}$

Another mitigating factor which had to be examined by the court was the advanced age of the appellant. He was 75 years old at the time of sentencing. The Court conceded that whilst advanced age is regarded as a

$24 \quad$ Hewitt v S para 11; S v Combrink 20121 SACR 93 (SCA) paras 22-24; S v Salzwedel 19992 SACR 586 (SCA) paras 12, 18; S v Sinden 19952 SACR 704 (A) 708F709B.

$25 \quad$ Hewitt $v S$ para 5.

$26 \quad$ Hewitt $v S$ para 5.

$27 \quad$ Hewitt $v S$ para 5.

$28 \quad$ Hewitt $v S$ para 5.

$29 \quad$ Hewitt $v S$ para 15

$30 \quad$ Hewitt $v S$ para 15.

$31 \quad$ Hewitt $v S$ para 15 
mitigating factor in our courts, ${ }^{32}$ it should not be seen as a bar to the sentence of imprisonment. ${ }^{33}$

The appellant also maintained that he had suffered greatly as a result of his tarnished status as a sports star. The SCA viewed this consideration in the following light:

\begin{abstract}
Much was made of the appellant's standing as a tennis icon who successfully represented his country internationally and the impropriety of imprisoning such an individual because his fall from grace (and the pain of the trial) was, in itself, sufficient punishment as he had 'already learned his lesson'. But this submission overlooks the basic tenets of our Constitution which decrees equality before the law. Our law knows no class distinctions of offenders of the proposed nature. The appellant's erstwhile celebrated status does not therefore earn him a special sentence. ${ }^{34}$
\end{abstract}

The court rightly noted that the Constitution provides that everyone is equal before the law and has the right to equal protection. ${ }^{35}$ The fact that Hewitt was a tennis icon did not negate the court's duty to apply the law equally.

\title{
3.1.2 Aggravating factors
}

The court noted that serious aggravating factors appeared in the matter. ${ }^{36}$ The appellant, a father of a young girl himself at the time, had exploited the complainants' innocence and taken advantage of them, while abusing the trust which the complainants and their parents had placed in him. ${ }^{37}$

In addition to the physical and psychological trauma, the complainants were also suffering from the lasting effects the offences had had on their lives and on those of their families. ${ }^{38}$ The first and second complainants were both divorced and had struggled to maintain their relationships due to the incidents. ${ }^{39}$

Also, the fact that the second complainant had laid a charge with the police had not deterred the appellant from committing further sexual crimes pertaining to the third complainant. ${ }^{40}$

$32 \quad S$ v Heller 19712 SA 29 (A) para 55D; $S$ v Munyai 19931 SACR 252 (A) 255G$256 \mathrm{~A}$.

$33 \quad$ Hewitt $v$ S para 15. See also S v Zinn 19692 SA 537 (A) 542B-C; S v Barendse 20102 SACR 616 (ECG) 619B-620B.

$34 \quad$ Hewitt $v S$ para 14

35 See s 9(1) of the Constitution of the Republic of South Africa, 1996.

$36 \quad$ Hewitt $v$ S para 11.

37 Hewitt $v$ S para 11.

38 Hewitt $v S$ para 11

$39 \quad$ Hewitt $v S$ para 12.

$40 \quad$ Hewitt $v S$ para 13. 


\subsection{Evaluation of the findings of the court}

The appellant's "fall from grace" and the "pain of the trial" are very compelling circumstances in mitigation of sentence. ${ }^{41}$ However, it is submitted that one cannot compare this pain with that suffered by the three complainants. Moreover, as a sports icon, one expects such an individual to be a moral custodian and an example to society, especially to youngsters.

In fact, the Court's argument in this regard focussed on equality before the law. It was rightly stated that Hewitt's rise and fall as a tennis icon could not be regarded as sufficient punishment. It is submitted that there should be no class distinction of offenders in our law and that equality is paramount.

The aggravating circumstances in this case, as mentioned before, were of an extreme nature. The appellant had been in a position of power and with this came great authority over young tennis players and their parents, who had trusted the retired star.

The fact that a perpetrator of rape or molestation is trusted by the child's parents makes the crime even more horrendous. ${ }^{42}$ Rape is a cruel and selfish act, in which the offender shows no feelings for the victim ${ }^{43}$ and which results in a brutal invasion of the victim's dignity and privacy, even more so if the victim is an innocent young girl who trusts the offender. ${ }^{44}$

Also, the fact that the appellant proceeded with the indecent assault of the third complainant even after he was suspended from the tennis association and had raped two girls, is regarded as an aggravating circumstance, as he had not shown any compassion for his victims. As a result of his actions, the lives of the complainants were forever changed and it was they who had to live with the trauma. After the appellant had pleaded not guilty to the charges, the matter had gone to trial and the complainants had had to relive the trauma they had experienced in the midst of the intense attention of the local and international media. ${ }^{45}$

$41 \quad$ Minimum sentences legislation as provided by the Criminal Law Amendment Act 105 of 1997 does not apply to the Hewitt case. The Act was not in operation at the time of the commission of the offences. The appellant probably would have faced life imprisonment if the Act had been in place at the time when the offences were committed.

$42 \quad$ Hewitt $v S$ para 9.

$43 \quad N v T 19941 \mathrm{SA} 862$ (C) 864G.

$44 \quad S v$ Chapman 19972 SACR 3 (SCA) 5B. In S v Jansen 19992 SACR 368 (C), it was held that the abhorrent abuse of male power places a considerable doubt on our claim to be regarded as a civilised society. See $S v$ Jansen 19992 SACR 368 (C) 378H-379A.

45 Hewitt $v$ S para 16. 
The SCA furthermore noted that the appellant had not accepted responsibility for the offences, since he had continued to maintain his innocence even after conviction. He also had not shown any remorse during the hearing of arguments in mitigation of his sentence, although the Court noted that his lack of remorse was not an aggravating factor. ${ }^{46}$ Nevertheless, it would have redounded in his favour if he had shown any sign of remorse for his deeds. ${ }^{47}$

Having considered the mitigating and aggravating circumstances, the SCA had to determine whether the sentence imposed by the trial court was appropriate and whether it had exercised its discretion in a proper manner. ${ }^{48}$ The SCA noted that it was regrettable that the complainants had had to wait for such a long time for justice to be served, especially in such cases, where the impact on the victim of the crime was so severe. ${ }^{49}$ Nonetheless, the Court praised the trial court and South African courts in general for delivering judgments despite the challenges posed by the lengthy delays. ${ }^{50}$ The Court said that the sentence imposed by the trial court, namely a sixyear prison sentence and the R100 000 condition of suspension were appropriate and that the trial court had exercised its sentencing discretion in a proper manner. ${ }^{51}$ Moreover, the Court stated that "the sentences fit the criminal and the crime and fairly balance the competing interests". ${ }^{2}$ By implying that the sentences "fit the criminal" the Court was comparing the wrongful acts committed by the appellant with the sentence as well as with the pain he had already suffered due to the media attention. It was submitted that the trial court and the SCA had given due consideration to the aggravating and mitigating circumstances in terms of the appellant's sentence. This task had been made very difficult as a result of the attention of the international media and the pressure from society. The Court also noted that the sentences would not rehabilitate the appellant since he was already at an advanced age. However, the sentences would still serve the primary purpose thereof, namely retribution and deterrence. ${ }^{53}$ While the appellant was being punished for his transgressions he was also being deterred from committing such crimes in the near future. Hewitt $v S$ para 16. For a comprehensive discussion of remorse and sentencing, generally see Du Toit 2013 Obiter 558-564.

$47 \quad$ Hewitt $v S$ para 16.

$48 \quad$ See Hewitt $v S$ para 17.

$49 \quad$ Hewitt $v S$ para 17.

$50 \quad$ See Hewitt $v$ S para 17.

$51 \quad$ Hewitt $v S$ para 17

$52 \quad$ Hewitt $v S$ para 17.

$53 \quad$ Hewitt $v S$ para 17.
} 


\section{Factors to consider when sentencing historical sexual offenders}

\subsection{Historical sexual abuse}

The conviction and sentencing of Mr Hewitt raise a number of issues such as that of the effective investigation and prosecution of "historical" sexual offences as well as the appropriate sentences for such crimes. Historical offences are crimes that are not discovered or reported shortly after the commission thereof. Especially in the case of child victims of sexual assault, a number of factors may contribute to the substantial delay in reporting the crime. ${ }^{54}$ The National Society for the Prevention of Cruelty to Children (NSPCC), a United Kingdom-based organisation, defines historical abuse as follows:

Non-recent abuse (also known as historical abuse) is an allegation of neglect, physical, sexual or emotional abuse made by or on behalf of someone who is now 18 years or over, relating to an incident which took place when the alleged victim was under 18 years old. ${ }^{55}$

Historical sexual abuse received worldwide attention with the exposure of the abuse of thousands of children by Catholic priests over the last few decades. In 2002 the Boston Globe reported that a former American Catholic priest, John J Geoghan, had abused over 130 children over a span of two decades. ${ }^{56}$ Most of his victims had been grammar school boys, the youngest victim a four-year-old boy. ${ }^{57}$ The Catholic Church had been aware of the abuse but instead of reporting the abuse to the authorities, the Church assigned him to a new parish every time the abuse became too evident. ${ }^{58}$

Richard Sipe defines the abuse in the Catholic Church and its impact on the Church as "the most profound crisis of its integrity since the earliest

$54 \quad$ Shead 2014 CICJ 56. Also see Calitz 2014 PELJ 2452-2486.

$55 \quad$ NSPCC 2017 https://www.nspcc.org.uk/preventing-abuse/signs-symptomseffects/non-recent-abuse/.

56 Spotlight Boston Globe 2002 https://www.bostonglobe.com/news/specialreports/2002/01/06/church-allowed-abuse-priest-for-years/cSHfGkTIrAT25qKGvBu DNM/story.html.

57 Spotlight Boston Globe 2002 https://www.bostonglobe.com/news/specialreports/2002/01/06/church-allowed-abuse-priest-for-years/cSHfGkTIrAT25qKGv BuDNM/story.html.

58 Cardinal Bernard F Law knew about Geoghan's problem since 1984 but did nothing to stop it. Cardinal Law quit after the scandal was revealed. Nevertheless, he was reassigned to a different parish in Rome shortly after he resigned. See Spotlight Boston Globe $2002 \quad$ https://www.bostonglobe.com/news/specialreports/2002/01/06/church-allowed-abuse-priest-foryears/cSHfGkTIrAT25qKGvBuDNM/story.html. 
centuries of its existence". ${ }^{59}$ In the 1980s the Catholic Church had to face a new scandal of sexual abuse on a weekly basis. ${ }^{60}$ Like children abused by any other class of offender, most child victims who are abused by priests seldom speak about the abuse or reveal the truth only many years later. This article does not examine the historical sexual abuse by catholic priests in detail. ${ }^{61}$ It is referenced here only in order to point to the extent of the crime of historical sexual abuse and its devastating impact on the victims of these crimes.

More recently, the issue of historical sexual offences is also receiving considerable attention in England and Wales with the Report of the Independent Review into the Investigation and Prosecution of Rape in London, ${ }^{62}$ an on-going Independent Inquiry into Child Sexual Abuse ${ }^{63}$ and Operation Yewtree, a police investigation. ${ }^{64}$ The latter has led to the conviction of a number of prominent persons for historical sexual abuse. ${ }^{65}$ A recent Court of Appeal case also dealt with a number of appellants in different historical sexual abuse cases. ${ }^{66}$ At the end of 2016 a 101 -year-old man was sentenced to a substantial term of imprisonment in Birmingham for historical sexual offences. ${ }^{67}$ More recently it was announced that the Metropolitan Police is investigating 255 sexual abuse allegations involving a number of football clubs in London. ${ }^{68}$

The focus of this discussion is on the issue of sentencing. What follows is a brief discussion of the South African position, followed by an equally brief comparative overview of the position in England and Wales. The Sentencing Council in England and Wales recently published a comprehensive set of guidelines concerning historical sexual abuse, hence the inclusion of

$59 \quad$ Sipe Sex, Priests, and Power 4. Generally, also see Plante and Daniels 2004 Pastoral Psychology 381-393.

$60 \quad$ Fedje 1991 Law \& Inequality 133.

61 For a comprehensive discussion of the abuse of children by Catholic priests, generally see Calitz 2004 PLJ 2452-2486; Isely 1997 Pastoral Psychology 277-299; Plante and Daniels 2004 Pastoral Psychology 381-393. Also see Sipe Sex, Priests, and Power 4. http://www.cps.gov.uk/publications/equality/vaw/dame_elish_angiolini_rape_review 2015.pdf.

For the definition of child sexual abuse in terms of the Report, see Anglioni 2015 http://www.cps.gov.uk/publications/equality/vaw/dame_elish_angiolini_rape_review 2015.pdf.

Gray and Watt 2013 https://www.nspcc.org.uk/globalassets/documents/researchreports/yewtree-report-giving-victims-voice-jimmy-savile.pdf. Smith 2014 https://www.theguardian.com/commentisfree/2014/jun/30/rolf-harrisconviction-vindication-operation-yewtree.

$66 \quad R v$ Forbes [2016] EWCH Crim 1388.

67 BBC News 2016 http://www.bbc.com/news/uk-england-38367103.

68 The Guardian 2017 https://www.theguardian.com/uk-news/2017/jan/30/met-police investigating-255-historical-football-sexual-abuse-allegations. 
England and Wales as a comparator. The sole focus is on specific factors to be considered in sentencing that are peculiar to historical sexual abuse cases. Neither the general principles of sentencing nor the specific approach to be followed in terms of the Criminal Law Amendment Act 105 of 1997, which prescribe discretionary minimum sentences for certain categories of serious sexual offences, have been dealt with, as much has been written about them. ${ }^{69}$ The factors mentioned hereunder will in any event form part and parcel of the traditional factors that need to be considered to determine whether "substantial and compelling" reasons exist to justifying the imposition of a lesser sentence than those prescribed by the Act. ${ }^{70}$ In any event, many historical crimes may have been committed prior to the implementation of the Act and will therefore not be subject to this sentencing regime. Furthermore, flowing from the legality principle as found in criminal law, prosecutors will often be bound to charge persons accused of historical sexual offences with common law offences or crimes under the Sexual Offences Act 23 of 1957 instead of offences provided for in the more refined Criminal Law (Sexual Offences and Related Matters) Amendment Act 32 of $2007 .{ }^{.1}$ The sentencing regime applicable at that time will also find application in such cases. ${ }^{72}$

\subsection{The position in South Africa}

Both the South African Supreme Court of Appeal and the Constitutional Court have provided valuable guidance on the approach to be followed when courts are confronted with allegations of historical sexual crimes. In $S$ $v$ Cornick $^{73}$ the first appellant was convicted on two counts of rape, and the second appellant on one such count. The incident leading to their conviction had occurred in 1983 - some nineteen years before the complainant laid charges against them. The complainant had been a child of fourteen at the time of the commission of the offences, and the appellants had been some four years older. ${ }^{74}$ The appellants were both 39 years old at the time of sentencing. The trial court sentenced the appellants to a term of five and four years' imprisonment respectively. ${ }^{75}$ At the time of the sentence the sentencing jurisdiction of the trial court was limited to ten years'

69 For a detailed discussion of the topic see Terblanche Guide to Sentencing ch 3 and especially 62-65, 73-87; Du Toit Commentary RS 56 ch 28 18D-2B - 18D-13; Van der Merwe 2002 CARSA 20-23. $S$ v Malgas 20011 SACR 469 (SCA) paras 9-10; Terblanche Guide to Sentencing 78.

71 Here, the principle of legality refers to the maxim nullum crimen sine lege, otherwise known as "no crime without law". See Burchell Principles of Criminal Law 35. Here, the principle of legality refers to the maxim nulla poena sine lege, otherwise known as "no punishment without law". See Burchell Principles of Criminal Law 40.

73 S v Cornick 20072 SACR 115 (SCA).

$74 S$ S Cornick 20072 SACR 115 (SCA) para 2.

$75 S v$ Cornick 20072 SACR 115 (SCA) paras 1, 44. 
imprisonment. ${ }^{76}$ The SCA recognised that sentencing in that matter was particularly difficult as evidence led before the trial court showed that the appellants had apparently lived exemplary lives since the commission of the crime. Both of them held stable jobs, had a regular income, and each had a wife and children. The court found that they were regarded as decent people by the communities in which they lived. ${ }^{77}$ The court dismissed the appeal, however, and concluded:

\begin{abstract}
While there is some cogency in the argument that men who have for twenty years led decent lives should not be sent to prison, I consider that the extreme cruelty of their behaviour warrants more than correctional supervision. Only direct imprisonment is sufficiently serious to constitute a deterrent and retributive sentence. ${ }^{78}$
\end{abstract}

Our courts must have a victim-centred approach to sentencing and courts must properly consider the impact of the crime on the victim. ${ }^{79}$ Both the SCA and Constitutional Court had on occasions referred to the sensitivity courts need to display towards victims of historical sexual crimes. In Van Zyl v Hoogenhout ${ }^{80}$ the Supreme Court of Appeal carefully considered the impact of sexual assaults on young victims.

The court referred to psychological studies and concluded:

In short, the expert evidence demonstrates that

(1) chronic child abuse is sui generis in the sequelae that flow from it;

(2) distancing of the victim from reality and transference of responsibility by the victim on to himself or herself are known psychological consequences;

(3) in the absence of some cathartic experience, such consequences can and often do persist into middle age despite the cessation of the abuse during childhood. ${ }^{81}$

Although a delictual matter, the reading of the case is essential for a criminal court to gain a general understanding of the impact of rape on young victims.

In Bothma $v$ Els $s^{82}$ the Constitutional Court recognised that the sexual abuse of children can bring about a delay in their "later lodging complaints as adults about such abuse". ${ }^{83}$ It is submitted that many of the factors

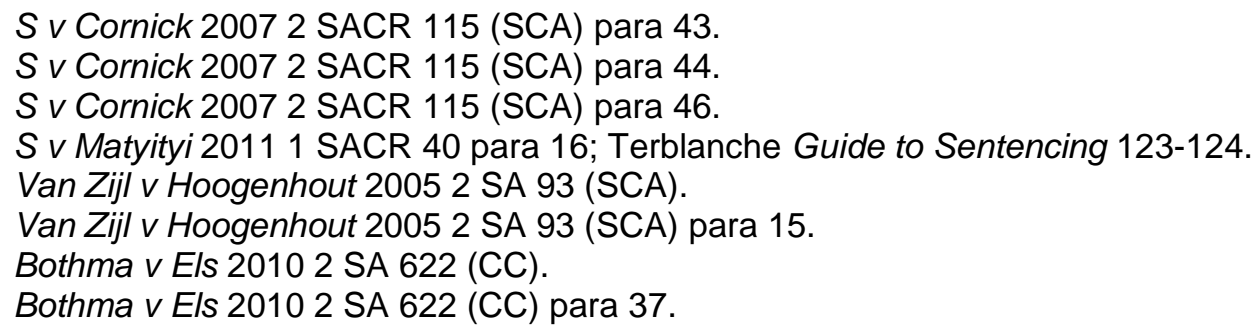


considered by the court in this regard are equally relevant in the consideration of an appropriate sentence. The court held that the criminal justice system should send out a clear message that no entitlement exists to commit the crime of rape. ${ }^{84}$ The court held that child rape "is an especially egregious form of personal violation". It is frequently characterised by secrecy and denial. ${ }^{85}$ The court held that a special public interest thus existed in taking action to discourage and prevent the rape of children. This was so, due to the fact that it often takes place behind closed doors and is committed by a person in a position of authority over the child. The result was the silencing of the victim, coupled with difficulty in obtaining eyewitness corroboration. The court held that complainants should be encouraged rather than be deterred when, breaking through feelings of fear and shame, they seek to bring to light past abuses against them. ${ }^{86}$ With reference to South African and foreign case law, the court made the point that non-reporting, incomplete reporting, and delays in reporting are common in cases of sexual abuse. Offenders "should not be permitted to reinforce their sense of entitlement by overlaying it with a sense of impunity". The court held that the knowledge that at some time the secret would be let out would act as a major deterrent against the sexual abuse of other similarly vulnerable children. ${ }^{87}$

\subsection{England and Wales}

The Sentencing Council of England and Wales has issued a definitive sentencing guideline ${ }^{88}$ for sexual offences committed in terms of current sexual offences legislation. ${ }^{89}$ Courts are generally obliged to follow the guideline. ${ }^{90}$ What follows is not a detailed explanation of the rather complex

$84 \quad$ Bothma v Els 20102 SA 622 (CC) para 46.

85 Bothma $v$ Els 20102 SA 622 (CC) para 47.

86 Bothma v Els 20102 SA 622 (CC) para 47. S 120 of the Coroners and Justice Act, 2009 provides for the issuing of definitive sentencing guidelines by the Sentencing Council. See in this regard Sentencing Council Sexual Offences: Definitive Guideline. The guideline came into effect on 1 April 2014.

Bothma v Els 20102 SA 622 (CC) para 66. The legislation referred to is the Sexual Offences Act, 2003.

Section 120 of the Coroners and Justice Act, 2009 provides for the issuing of definitive sentencing guidelines by the Sentencing Council. See in this regard Sentencing Council Sexual Offences: Definitive Guideline. The guideline came into effect on 1 April 2014.

Sentencing Council Sexual Offences: Definitive Guideline Annex B: Approach to Sentencing Historical Sexual Offences. The guideline applies to sexual offences under the Sexual Offences Act, 1956, or other legislation pre-dating the Sexual Offence Act, 2003.

Section 125(1) of the Coroners and Justice Act, 2009 provides that when sentencing offences committed on or after 6 April 2010: "Every court - (a) must, in sentencing an offender, follow any sentencing guideline which is relevant to the offender's case, and (b) must, in exercising any other function relating to the sentencing of offenders, follow any sentencing guidelines which are relevant to the exercise of the function, 
operation of the sentencing guideline system but rather a broad overview of the approach to be followed in cases of historical sexual abuse. It serves to provide guidance to South African sentencing courts from a merely functional perspective. The Sentencing Council has, as an annex to the sentencing guideline for sexual offences, published a sentencing guideline in respect of historical sexual offences. ${ }^{91}$ This guideline codified an earlier decision of the Court of Appeal. ${ }^{92}$ The guideline requires that a court apply the following principles. ${ }^{93}$ The offender must be sentenced in accordance with the sentencing regime applicable at the date of sentence and the sentence is limited to the maximum sentence available at the date of the commission of the offence. If the maximum sentence has been reduced, the lower maximum will be applicable. The court should have regard for any applicable sentencing guidelines for equivalent offences under the current sexual offences legislation. The seriousness of the offence, assessed by the culpability of the offender and the harm caused or intended, is the main consideration for the court. ${ }^{94}$ Some of the factors mentioned in the guideline which the court may use to determine the harm caused in cases of rape, for instance, are severe psychological and physical harm, additional degradation or humiliation, and violence or threats of violence, to name but a few. ${ }^{95}$ Some of the factors which impact upon the culpability of the offender are a significant degree of planning, the use of alcohol or drugs to facilitate the offence, the abuse of trust, previous violence against the victim, and if the offence was motivated by or demonstrated hostility to the victim based on sexual orientation or disability. ${ }^{96}$ The court should not seek to establish the likely sentence had the offender been convicted shortly after the date of the offence. When assessing the culpability of the offender, the court should have regard to the relevant culpability factors set out in any applicable guideline. The court must carefully assess the harm done to the victim based on the facts available to it, taking into consideration relevant harm factors set out in any applicable guideline. Consideration of the circumstances which brought the offence to light is of importance. The court must carefully consider the relevance of the passage of time, since it holds the potential of aggravating or mitigating the seriousness of the offence. It will be an aggravating factor if the offender has continued to commit sexual

unless the court is satisfied that it would be contrary to the interests of justice to do so." The guideline applies only to offender aged 18 and older.

\section{Sentencing Council Sexual Offences: Definitive Guideline Annex B.}

This was pointed out in $R v$ Forbes [2016] EWCH Crim 1388 para 2 with reference to $R v H$ [2011] EWCA Crim 2753.

All the principles referred to hereunder are contained Sentencing Council Sexual Offences: Definitive Guideline Annex B. Reference will therefore only be made to other parts of the guidelines that are mentioned.

Sentencing Council Sexual Offences: Definitive Guideline Annex B, Principles 1-4.

Sentencing Council Sexual Offences: Definitive Guideline 10.

Sentencing Council Sexual Offences: Definitive Guideline 10. 
offences against the victim or others, or has continued to prevent the victim from reporting the offence. Where there is an absence of further offending over a long period of time, especially combined with evidence of good character, this may be treated by the court as a mitigating factor. The State will be allowed to adduce evidence of bad character only once the accused has introduced evidence of good character. The more serious the offence, the less weight should normally be attributed to this factor. Where previous good character or exemplary conduct has been used to facilitate the offence, this mitigation should not normally be allowed and such conduct may constitute an aggravating factor. If the offender was very young and immature at the time of the offence, depending on the circumstances of the offence, this may be regarded as personal mitigation. If the offender made admissions at the time of the offence that were not investigated, this is likely to be regarded as personal mitigation. Even greater mitigation is available to the offender who reported himself to the police and/or made early admissions. A reduction for an early guilty plea should be made in the usual manner as provided for by the relevant guideline. ${ }^{97}$ Specific aggravating factors include the targeting of a vulnerable victim, blackmail or other threats made, the location and timing of the offence and steps to prevent the victim from reporting the incident. Mitigating factors include old age or a lack of maturity at the time of the commission of the offences. ${ }^{98}$

In the recent case of $R v$ Rolf Harris, ${ }^{99}$ the crown court was called upon to sentence a well-known TV personality, convicted on a number of counts of sexual offences. The presiding judge followed the principles set out in the guideline for historical sexual offences. He specifically referred to the following aggravating factors: the abuse of trust of the victims and of their parents; the considerable age gap between the offender and his victims; the nearby presence of others during the commission of the offences, the severe psychological injury the victims had suffered and the offender's lack of remorse. The court considered the impact of the crime on each victim individually. The court also referred to the courage of the victims to come forward as witnesses as they did not have the confidence to do so when the offences were committed. In mitigation the court considered the advanced age (84 years) of the offender and his ruined reputation, but added that he had only himself to blame for the loss of reputation. Despite his old age the

97 Sentencing Council Sexual Offences: Definitive Guideline Annex B, Principles 5-11.

98 Sentencing Council Sexual Offences: Definitive Guideline 11.

99 Courts and Tribunals Judiciary 2014 https://www.judiciary.gov.uk/judgments/r-v-rolfharris/. See Courts and Tribunals Judiciary 2013 https://www.judiciary.gov.uk/wpcontent/uploads/2014/05/sentencing-remarks-mr-j-turner-r-v-hall.pdf for similar remarks made in another high-profile case involving historical sexual abuse. 
court sentenced Mr Harris to an effective term of 5 years and 9 months' imprisonment.

\section{Conclusion}

Sexual abuse is a serious offence that should not be tolerated by any society and it is imperative for courts to sentence offenders who abuse others. This becomes even more important in the light of the historical sexual abuse of minors. The emotional and psychological harm caused by the abuse often leaves a permanent mark on the victim, especially if the abuse has gone unnoticed. The sentencing of such accused poses various challenges to courts. Not only may victims be reluctant to testify about the historical abuse; the offender might have rehabilitated. It is thus important for a court to assess the mitigating and aggravating factors in the light of the historical sexual abuse and its effects on the victim.

A number of factors emerge from the discussion, which are particularly relevant in cases of historical sexual abuse. More often than not, the victim was very young at the time of the commission of the offence against him or her. This inevitably is an aggravating factor, seeing that a vulnerable person had been exploited. Often a position of trust was also exploited. The court should carefully take into consideration the impact of the crime on the victim, especially the fact that the victim had often for a prolonged time lived with the experience, as our courts are obliged to give due regard to the impact of the crime on the victim. The psychological impact especially on child victims of historical offences was referred to above. Threats and steps to discourage the victim from exposing the crime must be regarded as aggravating. Moreover, the type of offender also plays a significant role in the potential abuse of a minor. This point is illustrated by the sexual abuse by catholic priests. While priests are well-respected members of the community, many of them have abused their power (and have used "the collar") to abuse children. Similarly Bob Hewitt, who was a highly regarded and respected individual, abused his own position to abuse the complainants. As a result, it naturally comes as a shock to the victims and the relatives of the victims when such a respected individual is revealed to be at the forefront of sexual abuse. This is an aggravating factor which the court should consider in historical sexual abuse cases. It becomes even more telling when a parent or close relative of the victim abuses the child.

Although old age may be a mitigating factor, the offender should not be allowed to hide behind it to escape a prison term. ${ }^{100}$ If the age gap between the older offender and the younger victim was huge at the time of the commission of the offence, this should serve as an aggravating factor. The

100 See, for example, S v Heller 19712 SA 29 (A) 55D. 
immaturity of the offender at the time of the commission of the offence may serve as a mitigating factor. ${ }^{101}$ As raised above, the offender's reputation should generally not be regarded as a mitigating factor, especially if his or her fame enabled him or her to commit the crime. It is clear that the position in South Africa and in England and Wales is that the seriousness of the offence and deterrence must remain the primary considerations. Apart from the fact that courts must send a clear message that sexual offences against children cannot be tolerated, the sentence should also empower victims to realise that the courts view the crimes against them in a serious light and that the perpetrators who might have been on the loose for many years are dealt with adequately.

\section{Bibliography}

\section{Literature}

Burchell Principles of Criminal Law

Burchell J Principles of Criminal Law $5^{\text {th }}$ ed (Juta Cape Town 2016)

Calitz 2014 PELJ

Calitz K "The Liability of Churches for the Historical Sexual Assault of Children by Priests" 2014 PELJ 2452-2486

Du Toit Commentary

Du Toit E Commentary on the Criminal Procedure Act (Juta Cape Town 2016)

Du Toit 2013 Obiter

Du Toit P "The Role of Remorse in Sentencing" 2013 Obiter 558-564

Fedje 1991 Law \& Inequality

Fedje J "Liability for Sexual Abuse: The Anomalous Immunity of Churches" 1991 Law \& Inequality: A Journal of Theory and Practice 133-161

Guerzoni and Graham 2015 IJCJ\&SD

Guerzoni MA and Graham H "Catholic Church Responses to Clergy-Child Sexual Abuse and Mandatory Reporting Exemptions in Victoria, Australia: A Discursive Critique" 2015 IJCJ\&SD 58-75

Isely 1997 Pastoral Psychology Isely PJ "Child Sexual Abuse and the Catholic Church: An Historical and Contemporary Review" 1997 Pastoral Psychology 277-299

101 For example, in Director of Public Prosecutions, Kwazulu-Natal v P 20061 SACR 243 (SCA) para 12, the Court held that "youth has always been a mitigating factor". 
Plante and Daniels 2004 Pastoral Psychology

Plante TG and Daniels C "The Sexual Abuse Crisis in the Roman Catholic Church: What Psychologists and Counselors Should Know" 2004 Pastoral Psychology 381-393

Sentencing Council Sexual Offences: Definitive Guideline Sentencing Council Sexual Offences: Definitive Guideline (Sentencing Council London 2013)

Shead 2014 CICJ

Shead K "Responding to Historical Child Sexual Abuse: A Prosecution Perspective on Current Challenges and Future Directions" 2014 CICJ 5573

Sipe Sex, Priests, and Power

Sipe AWR Sex, Priests, and Power: Anatomy of a Crisis (Brunner/Mazel New York 1995)

Terblanche Guide to Sentencing

Terblanche SS A Guide to Sentencing in South Africa $3^{\text {rd }}$ ed (LexisNexis Durban 2012)

Van der Merwe 2002 CARSA

Van der Merwe A "Guidelines on Sentencing in Child Sexual Abuse Cases" 2002 CARSA 20-23

\section{Case law}

Bothma v Els 20102 SA 622 (CC)

Director of Public Prosecutions, Kwazulu-Natal v P2006 1 SACR 243 (SCA)

Hewitt v S 20171 SACR 309 (SCA)

N v T 19941 SA 862 (C)

$R v$ Forbes [2016] EWCH Crim 1388

$R v H$ [2011] EWCA Crim 2753

S v Barendse 20102 SACR 616 (ECG)

S v Chapman 19972 SACR 3 (SCA)

S v Combrink 20121 SACR 93 (SCA)

S v Cornick 20072 SACR 115 (SCA) 
S v Heller 19712 SA 29 (A)

$S$ v Jansen 19992 SACR 368 (C)

$S$ v Malgas 20011 SACR 469 (SCA)

S v Matyityi 20111 SACR 40 (SCA)

S v Munyai 19931 SACR 252 (A)

S v Salzwedel 19992 SACR 586 (SCA)

S v Sinden 19952 SACR 704 (A)

S v Zinn 19692 SA 537 (A)

Van Zijl v Hoogenhout 20052 SA 93 (SCA)

\section{Legislation}

Constitution of the Republic of South Africa, 1996

Coroners and Justice Act, 2009

Criminal Law Amendment Act 105 of 1997

Criminal Law (Sexual Offences and Related Matters) Amendment Act 32 of 2007

Sexual Offences Act, 2003

Sexual Offences Act, 1956 (repealed)

Sexual Offences Act 23 of 1957

\section{Internet sources}

Anglioni 2015 http://www.cps.gov.uk/publications/equality/vaw/dame_ elish_angiolini_rape_review_2015.pdf

Anglioni E 2015 Report of the Independent Review into the Investigation and Prosecution of Rape in London http://www.cps.gov.uk/publications/equality/vaw/dame_elish_angiolini_rap e_review_2015.pdf accessed 31 January 2017 
BBC News 2016 http://www.bbc.com/news/uk-england-38367103 BBC News 2016 101-year-old Ralph Clarke Jailed for Child Sex Offences http://www.bbc.com/news/uk-england-38367103 accessed 31 January 2016

Courts and Tribunals Judiciary 2013 https://www.judiciary.gov.uk/wpcontent/uploads/2014/05/sentencing-remarks-mr-j-turner-r-v-hall.pdf Courts and Tribunals Judiciary $2013 R v$ James Steward Hall: Sentencing remarks of $\mathrm{Mr}$ Justice Turner https://www.judiciary.gov.uk/wpcontent/uploads/2014/05/sentencing-remarks-mr-j-turner-r-v-hall.pdf accessed 31 January 2017

$\begin{array}{llll}\text { Courts and Tribunals } & 2014\end{array}$ https://www.judiciary.gov.uk/judgments/r-v-rolf-harris/

Courts and Tribunals Judiciary $2014 R v$ Rolf Harris: Sentencing Remarks of Mr Justice Sweeny https://www.judiciary.gov.uk/judgments/r-v-rolf-harris/ accessed 31 January 2017

Gray and Watt 2013 https://www.nspcc.org.uk/globalassets/documents/ research-reports/yewtree-report-giving-victims-voice-jimmy-savile.pdf Gray D and Watt P 2013 Giving Victims a Voice: Joint Report into Sexual Allegation made against Jimmy Savile https://www.nspcc.org.uk/ globalassets/documents/research-reports/yewtree-report-giving-victimsvoice-jimmy-savile.pdf accessed 31 January 2017

NSPCC $2017 \quad$ https://www.nspcc.org.uk/preventing-abuse/signssymptoms-effects/non-recent-abuse/

National Society for the Prevention of Cruelty to Children 2017 Non-recent Abuse Support for Adults Abused as Children https://www.nspcc.org.uk/preventing-abuse/signs-symptoms-effects/nonrecent-abuse/ accessed 1 February 2017

Smith 2014 https://www.theguardian.com/commentisfree/2014/jun/30/rolfharris-conviction-vindication-operation-yewtree

Smith J 2014 The Rolf Harris Conviction is a Vindication of Operation Yewtree https://www.theguardian.com/commentisfree/2014/jun/30/rolfharris-conviction-vindication-operation-yewtree accessed 31 January 2017

Spotlight Boston Globe 2002 https://www.bostonglobe.com/news/specialreports/2002/01/06/church-allowed-abuse-priest-foryears/cSHfGkTIrAT25qKGvBuDNM/story.html Spotlight Boston Globe 2002 Church Allowed Abuse by Priest for Years https://www.bostonglobe.com/news/special-reports/2002/01/06/church- 
allowed-abuse-priest-for-years/cSHfGkTIrAT25qKGvBuDNM/story.html accessed 13 February 2017

The Guardian $2017 \quad$ https://www.theguardian.com/uknews/2017/jan/30/met-police-investigating-255-historical-football-sexualabuse-allegations

The Guardian 2017 Met Police Investigating 255 Historical Football Sexual Abuse Allegations https://www.theguardian.com/uk-news/2017/jan/30/metpolice-investigating-255-historical-football-sexual-abuse-allegations accessed 1 February 2017

\section{List of Abbreviations}

CARSA

CICJ

IJCJ\&SD

NSPCC

PELJ

SCA
Child Abuse Research a South African Journal

Current Issues in Criminal Justice International Journal for Crime, Justice and Social Democracy

National Society for the Prevention of Cruelty to Children

Potchefstroom Electronic Law Journal

Supreme Court of Appeal 